\title{
Waste Management Program at the Universidad Tecnologica de Leon
}

\author{
Dolores Elizabeth Turcott Cervantes*, Karina Guadalupe López Romo and \\ Mario Bernardo Reyes Marroquín
}

Universidad Tecnologica de Leon, Leon, Guanajuato, Mexico

\begin{abstract}
In Mexico a lot of educational institutions send their waste to places of final disposal, which generates a negative impact to the environment; especially when these places are not adequate and they do not comply with the current environmental legislation. This is why at the Universidad Tecnologica de Leon (UTL) it has been implemented a System of Environmental Management; where $83 \%$ of the negative impact (environmental aspects) is related to waste generation. This resulted in the creation and put into practice of a Waste Management Program.

Different actions have taken place to make the program work. For example, creating a plan for, the handling of valued waste, design and set forth of the infrastructure for the primary separation of waste, environmental education and promotion to the university's community about the adequate handling of the waste, among other things.

Also, one basic part of the program is the creation of indicators: in 2008, 2009, and 2010 the daily total generation of waste, per capita generation, the amount recovered in the storage center for its sale and eventual recycling as the waste used to elaborate natural fertilizer (compost). Therefore, in this article are shown the results obtained from the creation and implementing of the Management Waste Program of the UTL, which can be used as testimony and model to continue bettering the handling of waste inside educational institutions.
\end{abstract}

Keywords: Waste management, valued waste, composition of the waste, university campus.

\section{INTRODUCTION}

All activities inside the university campus cause in certain degree a negative impact to the environment. One of these impacts is the generation of waste. It is important that all educational institutions, mainly universities, to implement actions to not only support the caring of the environment, but also to contribute to the overall formation of the students. So they, the students can be more prepared for challenges in the near future.

In Mexico there are universities that have waste management programs, some of these examples are: UAM (Universidad Autonoma Metropolitana), UNAM (Universidad Nacional Autonoma de Mexico), Tecnologico de Monterrey (just some of their campus), Universidad Autonoma del Estado de Morelos, Universidad de Guadalajara, Universidad Autonoma de Baja California, Universidad Autonoma de San Luis Potosi, Instituto Tecnologico Autonomo de Mexico, Escuela de Estudios Superiores de Zaragoza. In Guanajuato, ITESI (Instituto Tecnologico Superior de Irapuato, which has an ISO 14001 certification), Universidad de Guanajuato, Universidad Iberoamericana de Leon, and Tecnologico de Monterrey Campus Leon (both are starting their programs), and Universidad Tecnologica de Leon.

In the Universidad Tecnologica de Leon (UTL) there has always been a concern for addressing and minimizing this negative impact. We have been the main promoters of this change: teachers and students of the Environmental

*Address correspondence to this author at the Universidad Tecnologica de Leon, Leon, Guanajuato, Mexico; Tel: (477) 710 0020, Ext. 311; Fax: (477) 710 0020, Ext. 610; E-mail: dturcott@utleon.edu.mx
Technology degree. In 2008, it has been said that the UTL was the only educational institution in Leon, Guanajuato (Mexico) which was closest to the concept of "a green university" [1].

Although the degree of Environmental Technology opened in 1998, and since then a lot of actions have been taken to protect the environment, it was not until 2006 that nine students did their evaluations to create a system of environmental management inside the university (named: SGA-UTL), with the purpose of formalizing and integrating the efforts done in the past and formulating significant and non-significant environmental aspects; taking as reference the ISO 14001.

Out of the 18 environmental aspects that were identified for the SGA-UTL, approximately $83 \%$ correspond to the impact caused by the UTL in the area of waste $[2,3]$. So, to follow-up and respond to the SGA-UTL, in 2008 started in a formal way, the WASTE MANAGEMENT PROGRAM in conjunction with the operation of a storage center, which helps with the collection, storage, and separation of the waste. The inorganic waste recovered is sold for later recycling and the organic waste is used to elaborate natural fertilizer (compost).

Just in 2008 the UTL generated 55.77 tons of waste (on average 0.2 tons per day), with this we can compare ourselves to other universities in Mexico; for example, in the Universidad Autonoma de Baja California (Mexicali I campus) one ton is generated a day [4], in Universidad Iberoamericana de Leon 0.16 tons are generated a day [5], in Universidad Autonoma Metropolitana 1.55 tons are generated a day $[6,7]$, this generation depends on many 
factors, mainly on the number of people inside the institution, later on we will discuss the generation per capita for a more accurate conclusion of this information.

As we can see, not much information exists about the generation of waste inside Mexican universities (per capita, total waste generation, composition of waste, etc.) [4], although some universities have their waste management program. Therefore, the main objective of this essay is to show the results obtained from at least 3 years at the UTL, to establish as precedent and testimony to continue bettering the handling of waste inside educational institutions in Mexico.

\section{BACKGROUND AND FIELD OF STUDY}

The Universidad Tecnológica de Leon is located in Leon, Guanajuato Mexico, and it was founded in 1995 [8]. In present time it offers around 10 degrees for TSU (University Superior Technician, level 5B, a level before Engineering). Among these degrees we have Environmental Technology. Besides this, an academic program exists in the afternoons to obtain the degree of Engineering. To offer the model 70-30 (70\% practice and $30 \%$ theory) a lot of specialized labs exist to be used by the students; three terms exist per year: January-April, May-August, and September-December. Today, around 3,486 people are in the university, among which are students, teachers and administrative personnel, see Table 1.

The waste management program started in 2007, with the storage center called Universitary Collecting Centre (UCC) or CUPA (Spanish acronym). Since then, the program offers service to the entire university by gathering, storing and separating waste. Three categories exist for the waste generated in the university: organic (green container), not organic (blue container), and garbage (black container). Not organic waste was sold for later recycling, the organic waste are used to produce natural fertilizer, and garbage is sent for final disposal at the sanitary landfill (see Fig. 1).

The whole university community (students, professors, and administrative personnel) deposit waste in each containers, then the collecting is made (just organic and inorganic waste are taken to UCC).

\section{MATERIALS AND METHODOLOGY}

To satisfy the needs of the university in regards to the handling of waste, a diagnose was made through a quantification of the waste, with the purpose of determining the indicators of generation and designing a waste management program according to the results obtained by the study. To complement the information obtained by the program, the following methodological steps took place:

Table 1. Diverse Sector Population at Universidad Tecnologica de Leon in 2009 and 2010

\begin{tabular}{|c|c|c|}
\hline & $\mathbf{2 0 0 9}$ & $\mathbf{2 0 1 0}$ \\
\hline \hline Students & 1513 & 2834 \\
\hline Full time Professors & 117 & 131 \\
\hline Administrative $^{1}$ & 117 & 130 \\
\hline Half time Professors & 274 & 391 \\
\hline Special projects & 1 & 0 \\
\hline Service $^{2}$ & N.D. & N.D. \\
\hline
\end{tabular}

Includes personnel in labs and information center.

${ }^{2}$ Includes Cafeteria service, cleaning and surveillance, which are external companies constantly rotating, but only represent less than $2 \%$ of the population.

\section{Special Waste Handling Plan}

The sources of waste generation were determined to make a qualitative analysis (separation indicators) and afterwards a quantitative analysis (as mentioned in point 2), through the establishment of each source, the kinds of waste were established from its generation to its sale; the specific needs and determining of responsibilities of certain aspects such as: the generation, containment, internal collection, storage, primary and secondary separation, the original plan written by Lopez in 2008 [9], and continuing with actualization through indicators of the section 3 (indicators calculation).

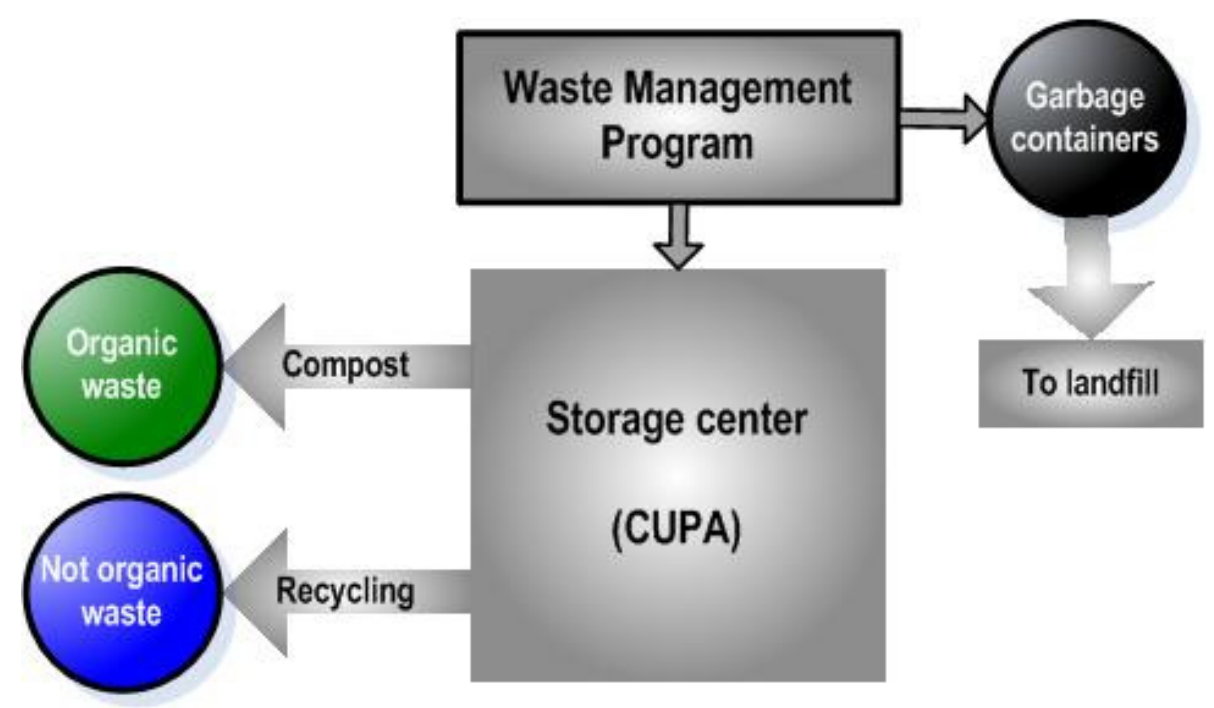

Fig. (1). Operation diagram of the storage center and destination of the waste. 


\section{Quantitative Analysis}

Three analysis were made: one from June 2 to June 6 of 2008, another from June 22 to July 18 of 2009, and the last one from February 15 to March 6 of 2010, excluding Sundays; to quantify the production of waste from each source (the samples correspond to two terms from the university: January-April and May-August). Once collected, the samples were classified by source of generation, their physical properties were measured and determined (such as their density and volume), as also their composition.

\section{Indicators Calculation}

The indicators were determined from the sampling done in the quantitative description, to evaluate the efficiency of the plan, such as: total generation, per capita generation, percentage of waste recovered and kilograms of waste sent to the sanitary landfill, kilograms sent to recycling. Also, the different factors that vary waste generation inside the campus were analyzed, some of which are: holidays, professional practice, graduations, cultural events and others that are detailed further along.

Some of the data and indicators were obtained through the measuring of waste that entered the storage center (UCC), where the control of these measures is done through an electronic log:

- Waste subject to appreciation such as: PET, HDPE, cardboard, metal, aluminum, paper, and glass were collected, quantified and stored in UCC for later sale.

- With the organic waste, these were collected from the cafeteria, gardens and some of the waste containers in the university to elaborate natural fertilizer (compost).

- The waste that do not have a recuperation potential or that cannot be used as natural fertilizer were deposited in garbage containers, where they are taken to the sanitary landfill. The measurements of this waste are used to create an operational performance indicator [10]: total of waste sent for final disposal (kilograms sent to the sanitary landfill).

\section{Containment Infrastructure Proposal}

According to the needs detected in each of the sources of generation as a result of the previous sampling, some proposals were made for the acquisition and distribution for the containment infrastructure for each of the buildings; including the capacity evaluation $\left(\mathrm{m}^{3}\right.$ - cubic meters) of the general garbage containers (where they are stored until the local authorities take them to the landfill).

\section{Environmental Education}

An educational campaign was put into action for the entire university's community about the appropriate separation of the waste in the different containers inside the university with the intention of increasing the separation indicators and collecting of appreciable waste; and therefore, reducing the amount of waste that are sent to final disposal.

\section{RESULT AND DISCUSSION}

\section{Special Waste Handling Plan}

This handling plan includes, among other things: a qualitative analysis of waste and the different flow diagrams of the methods established for waste handling.

\subsection{Qualitative Analysis}

From the revision made, 16 sources of generation were identified inside the university, which are shown on Table 2.

Table 2. Waste Generation Sources Related to Specific Activities

\begin{tabular}{|c|c|}
\hline Source of Generation & Activities \\
\hline \hline Buildings (A, B, C, D, E, F) & Classes, administrative offices \\
\hline Cafeteria & Catering \\
\hline Laboratories (A, B, C) & Specialized education by degree \\
\hline Link Center & $\begin{array}{c}\text { Conferences, administrative } \\
\text { work and publicity }\end{array}$ \\
\hline Information Center & Book lending, magazines, etc. \\
\hline Gardens & Fun and recreation \\
\hline Football field and basketball courts & Fun and recreation \\
\hline Maintenance & Facility and equipment maintenance \\
\hline Construction areas and remodeling & Construction activities \\
\hline
\end{tabular}

Note: all buildings have two floors, except the Information Center and Cafeteria. Source: Modified and upgraded since [9].

Table 3. Waste Classification in the Universidad Tecnologica de Leon

\begin{tabular}{|c|c|c|c|c|}
\hline Paper and newspapers & Books and notebooks & Metalized wrappings (cookies, potato chips) & Brochures & $\begin{array}{l}\text { Organic } \\
\text { Cookies }\end{array}$ \\
\hline Folders & Invitations & Plastic sheets & Gum & Food scrap \\
\hline Magazines & Paper & Plastic bags and tetra pack (juice, milk) & Compact Discs & Garden waste \\
\hline Manuals & Soda bottles & Pens & & \\
\hline Calendars & Water bottles & Diapers & & \\
\hline Carton boxes & Yoghurt bottles & Toilet paper & & \\
\hline Pen boxes & Glass & Fruit containers & & \\
\hline
\end{tabular}


Once identified the sources of waste generation, a qualitative description was made from each obtaining different results. Table 3 shows waste that is deposited in each of the containers according to their classification inside the university (organic, inorganic and garbage). It is important to clarify that carton, office paper (books and notebooks), mixed paper (magazines and invitations), newspapers, etc, are considered as inorganic because each are subject to sale and recycling (that is the internal classification corresponding to the different containers).

Even though people know in which container goes what kind of waste (due to environmental education), sometimes they do not deposit the garbage in its correct place. The results of a qualitative separation are shown below in Table 4; this sample was taken in 2008.

\subsection{Flows Diagrams of Waste Handling}

Five flow diagrams were created according to the handling of each appreciable waste, which include: newspaper, office paper, mixed paper, organic waste and carton, there also exist flow diagrams that include the handling of dangerous waste such as: electronic appliances, serigraphy waste, electronic devices, fluorescent lamps, used batteries and waste from the different labs. Each procedure shows the specific needs and assignation of responsibilities for the handling of each waste. All the flow diagrams are available for the university's community through our quality website: http://calidad.utleon.edu.mx/access/index.php, and form part of the environmental aspects of SGA-UTL.

\section{Quantitative Analysis}

The results obtained from the sampling are shown in Table $\mathbf{5}$ (divided by sources of generation), including average weight, obtained in 2008, 2009 and 2010 with their respective standard deviation. In all the data we can observe that the greatest generation of waste is produced by activities from the Cafeteria, and the least generation of waste is variable depending the year.

The volume and density measurements are shown in Table 6, where we can observe that the cafeteria is one of the highest in regards to volume and density, given that its composition is from organic waste (food) and Styrofoam.

Table 4. Qualitative Description of the Waste Containers

\begin{tabular}{|c|c|c|c|}
\hline \multirow{2}{*}{ Source } & \multicolumn{3}{|c|}{ Container } \\
\cline { 2 - 4 } & \multirow{2}{*}{ Organic } & Inorganic & Garbage \\
\hline \hline Building A & S & S & R \\
\hline Building B & R & I & I \\
\hline Building C & S & I & I \\
\hline Building D & I & S & S \\
\hline Building E & N.D. & N.D. & N.D. \\
\hline Building F & UN & R & UN \\
\hline Lab A & S & S & R \\
\hline Lab B & S & S & R \\
\hline Lab C & S & I & I \\
\hline Cafeteria & I & I & S \\
\hline Link Center (CVD) & R & S & S \\
\hline Information Center & S & I & I \\
\hline
\end{tabular}

UN = Unacceptable (separation between 0-25\%).

I = Insufficient (separation between $26-49 \%$ ).

$\mathrm{R}=$ Regular (separation between 50-75\%)

$\mathrm{S}=$ Sufficient (separation between 76\%-99\%).

$\mathrm{E}=$ Excellent (separation to $100 \%$ ).

N.D. = No data, because in 2008 , the building wasn't in use, yet.

Table 5. Average Weight of Waste (Organic, Inorganic and Garbage) for Each Source of Generation

\begin{tabular}{|c|c|c|c|c|c|c|}
\hline $\begin{array}{c}\text { Year } \\
\text { Source }\end{array}$ & \multicolumn{2}{|c|}{2008} & \multicolumn{2}{|c|}{2009} & \multicolumn{2}{|c|}{2010} \\
\hline Building B & 19.22 & 6.86 & 20.44 & 10.86 & 23.94 & 14.85 \\
\hline Building $\mathrm{C}$ & 13.60 & 13.47 & 9.77 & 5.83 & 37.57 & 18.00 \\
\hline Building $\mathrm{E}^{1}$ & - & - & 9.26 & 8.10 & 4.91 & 4.35 \\
\hline Building F & 13.37 & 7.07 & 4.76 & 3.83 & 7.79 & 7.25 \\
\hline Cafeteria & 64.91 & 11.04 & 25.01 & 14.87 & 47.24 & 24.41 \\
\hline CVD & 12.27 & 11.87 & 4.28 & 2.17 & 6.31 & 7.51 \\
\hline Lab. C & 8.01 & 5.18 & 5.32 & 5.56 & 8.41 & 4.79 \\
\hline Paper containers ${ }^{2}$ & - & - & 17.67 & 12.19 & 3.09 & 3.05 \\
\hline Garden waste $^{3}$ & - & - & 184.00 & - & - & - \\
\hline
\end{tabular}

${ }^{1}$ In construction during 2008.

${ }^{2}$ In 2008 there aren't measurements of the paper containers.

${ }^{3}$ In 2009 the garden waste could just be sampled, the average of generation was obtained through one month of measuring. 
Table 6. Average Volume and Density of Waste (Organic, Inorganic and Garbage) by Each Generation Source

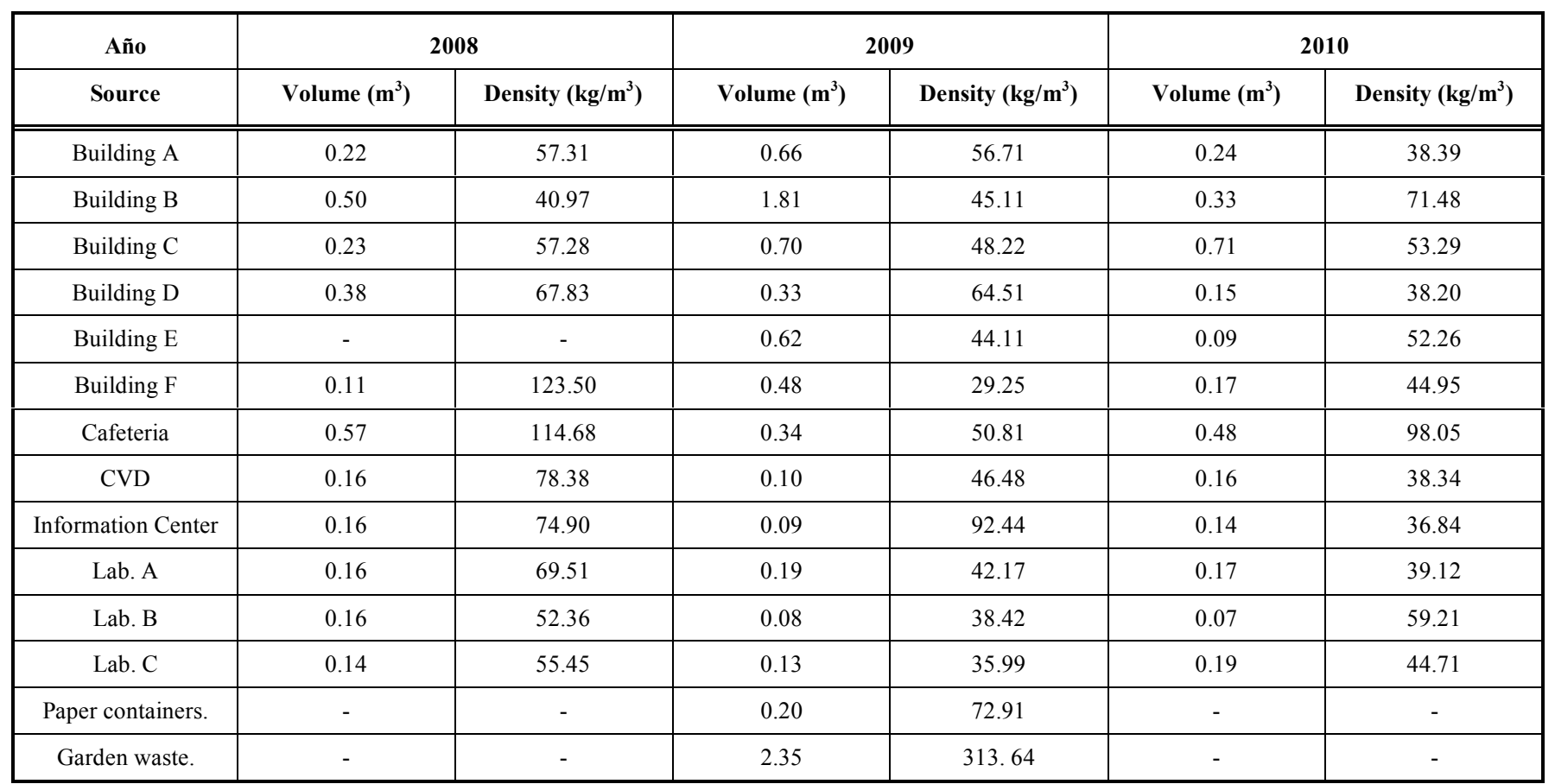

In Table 7 it can be observed the composition of the waste generated inside the university, having as the greatest generation of waste the organic matter (composed mainly by the cafeteria waste) and toilet paper, in this composition are excluded the garden waste due to that its generation is seasonal (spring, summer, autumn and winter).

\section{Indicators Calculation}

The total average generation of waste in 2008 was $202.065 \mathrm{~kg} /$ day, with a standard deviation of 92.055 and a per capita generation of $0.08 \mathrm{~kg} /$ person a day, with a population of approximately 2,525 people. In that year the storage center recuperated the $25.6 \%$ of the total waste generated in the university, which represents $48 \%$ of the recoverable waste, as shown in (Fig. 2).

In 2009, the total average generation of waste was 147.47 $\mathrm{kg} /$ day and the per capita generation was $0.05 \mathrm{~kg} / \mathrm{person}$ a day, and the percentage of recovered waste in the storage center was $29.76 \%$, it is important to mention that the goal for the SGA-UTL was $25 \%$, so from that moment on we started improving the environmental education program for the university community, although this number was good, the percentage of appreciable waste decreased from $46 \%$ in 2008 to $34.1 \%$ in 2009 .

Finally, in 2010 the total average of generation went from $220.01 \mathrm{~kg} /$ day and a per capita generation 0.063 $\mathrm{kg} /$ person a day, and yet we cannot compare with 2008 and 2009 given that 2010 is still in progress while this article is being written and we don't have the results for all the year.

During work days in the university in 2008, 2009, and 2010 (present) $[11,12]$, the measurements were made of the appreciable waste that entered the storage center. (Fig. 3) shows the amount of waste that entered the storage center for appreciation, since January until December [13].
Table 7. Percentage by Weight

\begin{tabular}{|c|c|c|c|}
\hline Waste & 2008 & 2009 & 2010 \\
\hline Organic matter & $33.97 \%$ & $23.45 \%$ & $29.80 \%$ \\
\hline Toilet paper & $21.35 \%$ & $18.00 \%$ & $15.38 \%$ \\
\hline Carton & $8.18 \%$ & $5.33 \%$ & $4.10 \%$ \\
\hline PET & $8.10 \%$ & $5.46 \%$ & $5.00 \%$ \\
\hline LDPE & $3.12 \%$ & $3.70 \%$ & $4.00 \%$ \\
\hline Markers & $2.89 \%$ & - & $0.03 \%$ \\
\hline Glass & $2.88 \%$ & $2.77 \%$ & $9.00 \%$ \\
\hline File paper & $2.59 \%$ & $4.52 \%$ & $3.04 \%$ \\
\hline Styrofoam & $2.08 \%$ & $2.03 \%$ & $4.00 \%$ \\
\hline HDPE & $2.04 \%$ & $1.89 \%$ & $2.00 \%$ \\
\hline Polypropylene & $1.98 \%$ & $1.24 \%$ & $6.00 \%$ \\
\hline Tetrapack & $1.93 \%$ & $1.71 \%$ & $1.69 \%$ \\
\hline Waxed paper & $1.73 \%$ & $1.07 \%$ & - \\
\hline Napkins & $1.32 \%$ & $6.77 \%$ & - \\
\hline Mixed paper & $1.07 \%$ & $4.96 \%$ & $1.50 \%$ \\
\hline Aluminum & $1.02 \%$ & $0.82 \%$ & $1.40 \%$ \\
\hline Waxed carton & $0.84 \%$ & $0.35 \%$ & - \\
\hline Newspaper & $0.80 \%$ & $0.43 \%$ & $0.13 \%$ \\
\hline Metal & $0.64 \%$ & $0.96 \%$ & $1.00 \%$ \\
\hline Garden waste & $0.51 \%$ & $0.39 \%$ & - \\
\hline Construction waste & - & $6.14 \%$ & - \\
\hline Electronic waste & - & $3.39 \%$ & - \\
\hline Wrappings & - & $1.40 \%$ & $3.00 \%$ \\
\hline Oil & - & - & $1.00 \%$ \\
\hline $\mathrm{PVC}$ & - & - & $1.00 \%$ \\
\hline Fine waste & $0.73 \%$ & $3.11 \%$ & $6.12 \%$ \\
\hline Other* & $0.23 \%$ & $0.12 \%$ & $0.81 \%$ \\
\hline
\end{tabular}

* Includes: sponge, dust, mop, clothes, cotton, gauze, batteries, porcelain, CDs, soap, cord, tow, wood. 


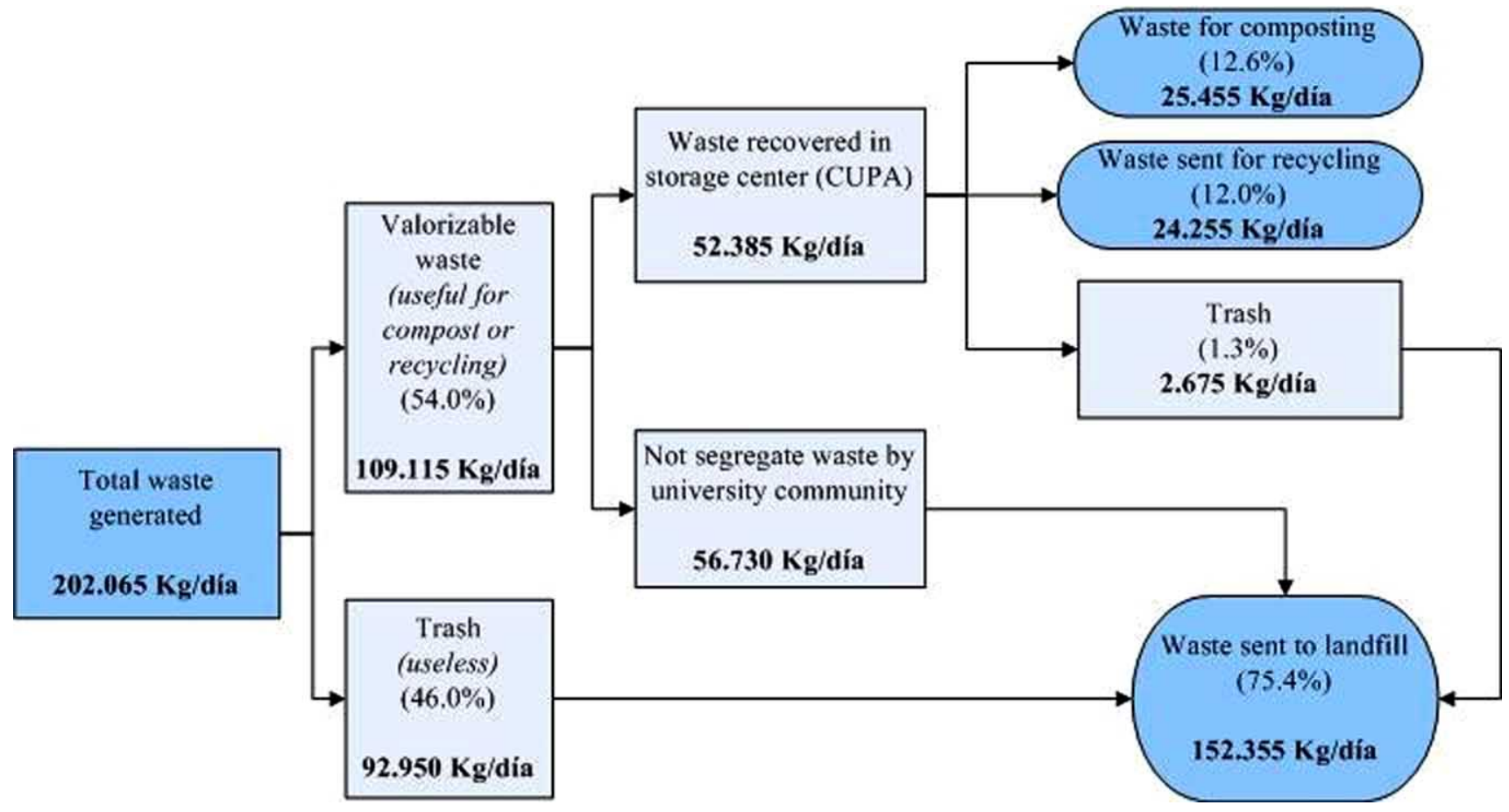

Fig. (2). Balance generation, recuperation and no recuperation of waste in 2008.

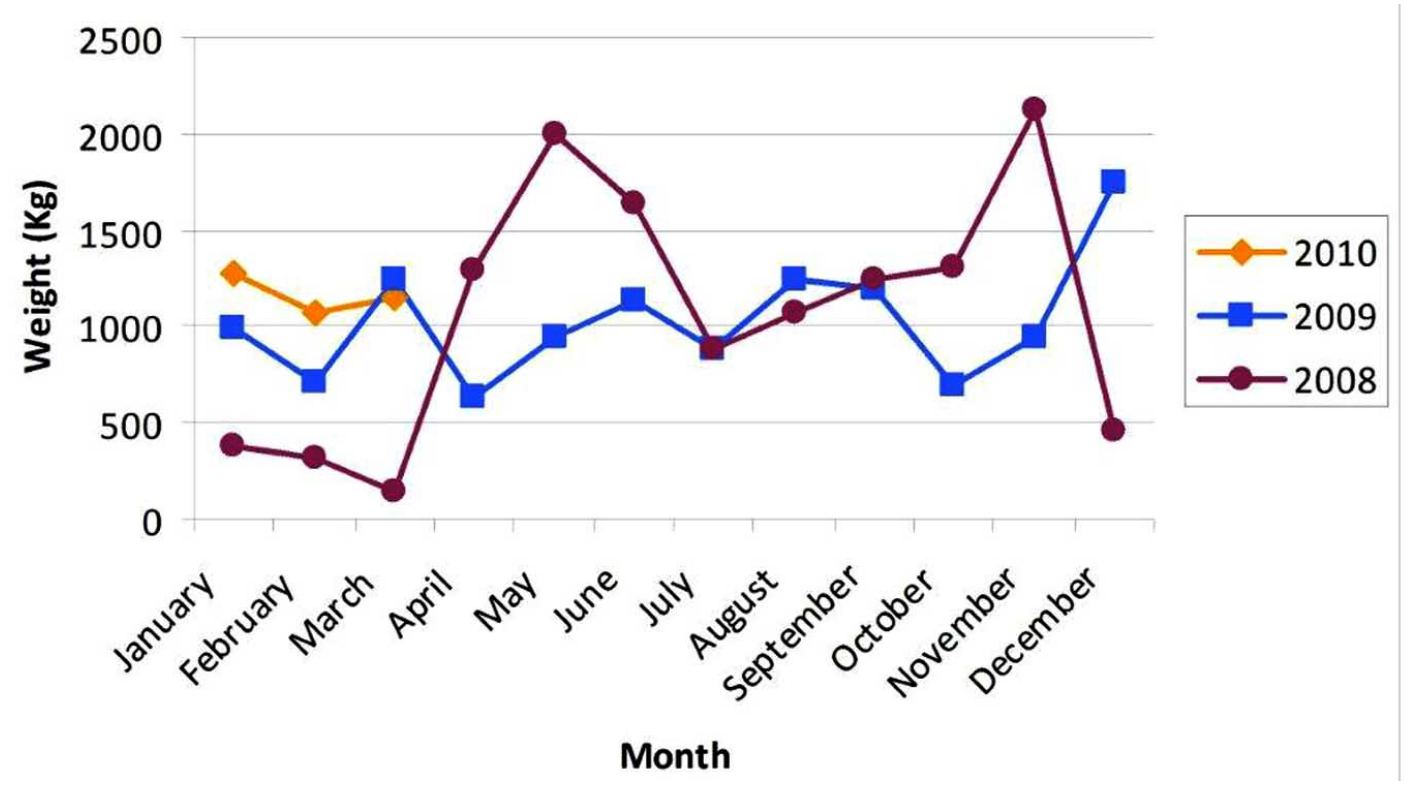

Fig. (3). Amount of recoverable waste that entered the storage center for their recuperation in 2008, 2009, and partially in 2010.

In 2008, the total amount of waste recovered in the storage center was 14.52 tons, in 2009 it was 12.33 tones, and data for 2010 is still unavailable. It is important to clarify that even though the recovering of waste was greater in 2008 than 2009 , the percentage of recovered waste was greater in 2009 as it was mentioned before.

The composition of the waste separated for their appreciation and later sale o conversion into natural fertilizer, is shown on Table 8. In the column of 2008 is included some waste of 2007 (November and December).
From the cafeteria the greatest amount of recovered waste is organic, with the only objective of producing natural fertilizers monthly, to be used in the green areas of the university. Also a great deal of carton was generated and office paper due to its consumption in office areas and this is sold for recycling.

Approximately $95 \%$ of the waste that enter the storage center are recovered, on average $5.1 \%$ of the waste are returned in the general garbage containers, which will be taken to the sanitary landfill (see Fig. 2). According to the 
Table 8. Composition of Recovered Waste in the Storage Center

\begin{tabular}{|c|c|c|c|}
\hline Waste & $\begin{array}{c}\text { Kg Recovered } \\
2008\end{array}$ & $\begin{array}{c}\text { Kg Recovered } \\
2009\end{array}$ & Treatment* \\
\hline Aluminum & 54.27 & 76.42 & Recycled \\
\hline Carton & 1215.83 & 393.3 & Recycled \\
\hline Wood & 10.20 & - & Compost \\
\hline Ferrous Metal & 42.31 & 71.62 & Recycled \\
\hline Organic waste & 6907.23 & 7040.4 & Compost \\
\hline File paper & 1948.44 & 2316.3 & Recycled \\
\hline Mixed paper & 630.26 & 511.6 & Recycled \\
\hline HDPE & 182.65 & 374.5 & Recycled \\
\hline Newspaper & 1084.610 & 279.4 & Recycled \\
\hline PET & 626.544 & 754.55 & Recycled \\
\hline Glass & 354.790 & 507.55 & Recycled \\
\hline $\begin{array}{l}\text { Trash from the } \\
\text { storage center }\end{array}$ & 738.296 & N.D. & Landfill \\
\hline
\end{tabular}

chart, the waste that is generated in least amount include: wood, aluminum, and ferrous metal. In this case, aluminum is collected by the cleaning personnel before it arrives to the storage center.

The generation inside the university is affected by diverse factors, shown in Table 9. One of the main factors that influences in the increment or decrement of the waste is the amount of students on each term. One of the main factors for decreasing waste production is holidays.

\section{Containment Infrastructure Proposal}

Fig. (4) shows the external islands that are used for the separation of waste; each island has 3 containers: the blue one is used to collect inorganic waste, the green one for organic waste, and the black one for garbage. The university has 27 islands for separating and containing the waste outside the buildings; the capacity for each island is 0.488 $\mathrm{m}^{3}$, having a maximum capacity of $13.16 \mathrm{~m}^{3}$. There also exist three general containers for garbage, where waste is contained to be taken to the sanitary landfill, where two containers have the capacity of $7.46 \mathrm{~m}^{3}$ and the other one $9.5 \mathrm{~m}^{3}$.

In the same way, 33 islands exist inside the buildings to separate the waste, these islands have less capacity (each one has a capacity of $0.233 \mathrm{~m}^{3}$ ), for a total capacity of $7.7 \mathrm{~m}^{3}$. There also exist 24 containers to separate paper and carton. The location of each container is specified by the sources of generation explained before.

For the operation of the storage center and separation of waste we have a space of $147 \mathrm{~m}^{2}$ (square meters) with walls and a roof, and we also have a New Holland vehicle that is used for the internal collection of waste and maintenance of the natural fertilizer.

According to the previous analysis, a requisition of more external and internal islands was made to cover the needs of the new areas, as also the acquisition of more paper containers. In the case of the waste containers a requisition was made for an additional container to satisfy the needs for an adequate contention capacity. The average density of the waste was $43.13 \mathrm{~kg} / \mathrm{m}^{3}$ so a new waste container was required to avoid cleanness issues and to have the capacity required for contention special events take place at the university.

Table 9. Monthly Factors Involved in the Generation y Recuperation of Waste in 2008

\begin{tabular}{|c|c|}
\hline Month & Factor(s) \\
\hline January & The collecting of waste was affected by the little knowledge from the university's community about the program of waste handling. \\
\hline February & The generation decreased because of the amount of holidays in the university. \\
\hline March & The decrease of the generation was affected because of holidays (two weeks: holy week). \\
\hline April & $\begin{array}{l}\text { The increase of waste was caused by a special event called "Jornadas". Usually different kinds of cultural events happen: sports, } \\
\text { workshops, conferences, get-togethers. In these events the amount of certain waste increases (organic, carton). }\end{array}$ \\
\hline May & $\begin{array}{l}\text { The increase of waste (generally organic, office paper and mixed paper) is due to the meals given to teachers during staff training } \\
\text { week; which occurs the last week of the term. From this month till the end of summer, the generation of garden waste increases. }\end{array}$ \\
\hline June & $\begin{array}{l}\text { The high recovering of appreciable waste was because a description was made this month, additionally we had the celebration of TSU } \\
\text { day (student's day) that generates a lot of organic waste, carton, PET, and food leftovers. }\end{array}$ \\
\hline July & Waste generation was affected by summer vacation ( 2 weeks) \\
\hline August & $\begin{array}{l}\text { Once more the generation and recovering of waste was affected by vacation time at the end of the term. Organic waste increased } \\
\text { because of the staff training week to professors. }\end{array}$ \\
\hline September & $\begin{array}{c}\text { Because the new students who enter the campus don't know the waste handling program it affects the recovering of appreciable waste } \\
\text { and increases garbage generation. }\end{array}$ \\
\hline October & Educating the entire community about the correct way of separating waste caused an increment in the recovery of appreciable waste. \\
\hline November & Waste increased because of graduation ceremonies and other events inside the university. \\
\hline December & The decrease of waste was due to vacation time in this month. \\
\hline
\end{tabular}




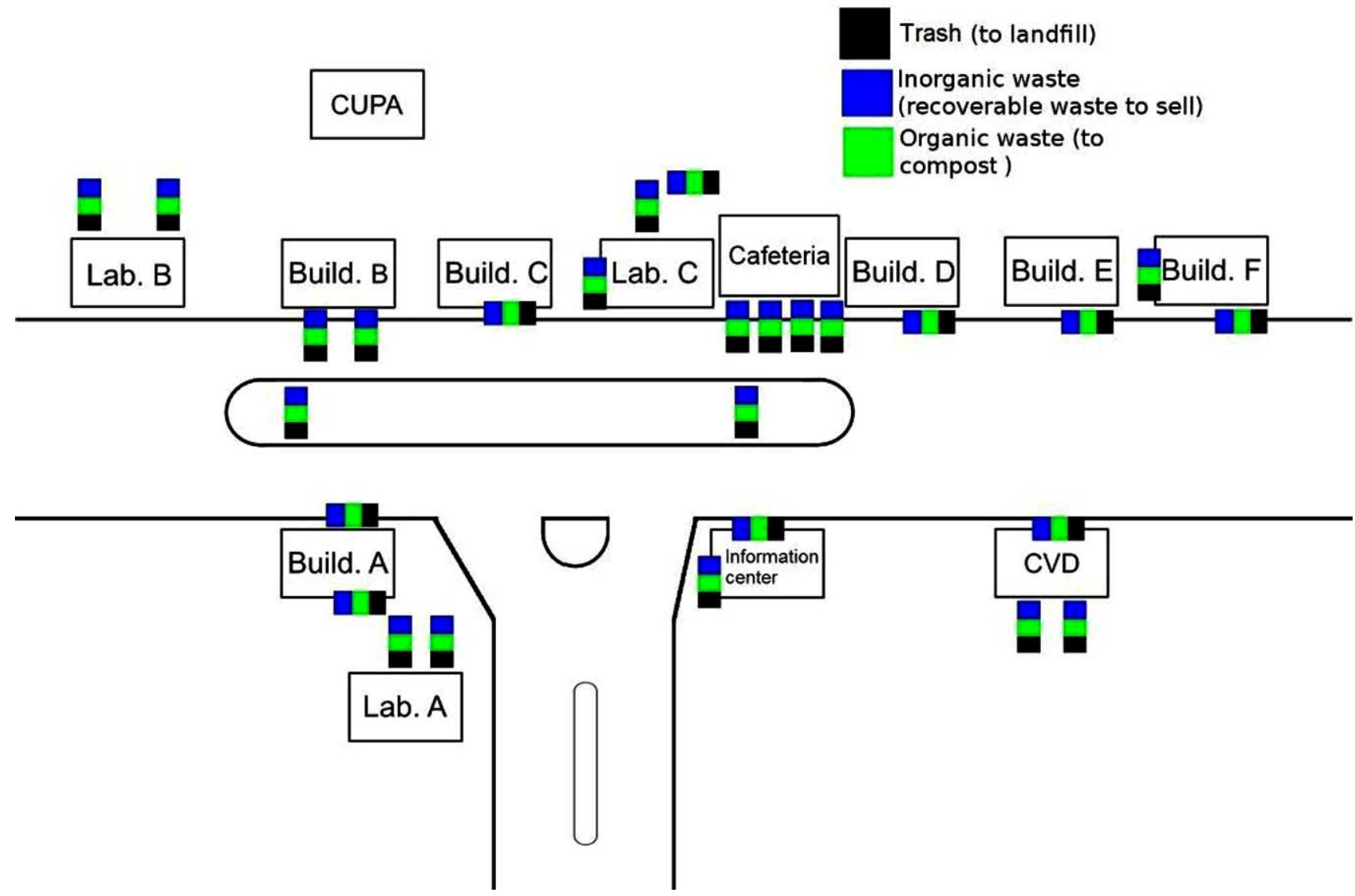

Fig. (4). Distribution of the exterior islands of the buildings.

\section{Environmental Education}

An environmental education campaign was put into action to demonstrate to the university community about the correct separation of the waste in the different containers inside the university (awareness campaigns, video, surveys, talks, forums, etc.) with the purpose of incrementing the indicators of separation and recovering of appreciable waste, and reducing the amount of waste sent for final disposal. The administrative personnel, teachers, and students that were trained during this campaign are shown on Table $\mathbf{1 0 .}$

\section{CONCLUSIONS}

The generation of waste inside the university is variable due to various factors, such as: number of students, holidays, and special events, among others. The UTL is not alien to these factors.

The waste management program has worked since 2008 in conjunction with the storage center with the intention of following up to all actions focused towards a comprehensive handle of waste. To increase the efficiency of the primary separation, permanent environmental educational campaigns

Table 10. Number of People Trained by Area

\begin{tabular}{|c|c|c|}
\hline Program or Area & Number of People Trained 2008 & Number of People Trained 2009 \\
\hline Industrial Electromechanics & 390 & 351 \\
\hline Information Technologies & 484 & 361 \\
\hline Economical Administrative & 563 & 551 \\
\hline Sustainability for Development ${ }^{1}$ & 155 & 95 \\
\hline Guided Visits & 99 & 0 \\
\hline Administrative and supporting personnel & 60 & 7 \\
\hline Others $^{2}$ & - & 640 \\
\hline TOTAL & 1751 & 2005 \\
\hline
\end{tabular}

${ }^{1}$ Includes the degree of Environmental Technology.

${ }^{2}$ Includes students from Engineering and reinforcement in environmental education to students of 2008. 
have been implemented for teachers, administrative personnel, directors, cleaning personnel, and students. All this has the intention of creating awareness of the importance of waste handling inside the university. The recovering percentage in 2009 it was better than 2008, and in the beginning of 2010 the amount of waste recovered seems to be better than 2008 and 2009. In fact, January 2008 is not representative due to the fact that the program was barely starting, and in that year a lot of factors affected the generation of waste, but by 2009 and 2010, we expect that the consolidation of this program could be clearly perceived.

The generation per capita calculated during the sampling was $0.08 \mathrm{~kg} /$ day (2008), $0.05 \mathrm{~kg} / \mathrm{day}(2009)$, and $0.063 \mathrm{~kg}$ /day (2010), compared to other universities in Mexico, it is inside a range of +0.02 to $-0.05 \mathrm{~kg} /$ person a day:

- Universidad Iberoamericana de León, Guanajuato, México: $0.041 \mathrm{~kg} /$ person / day [3]

- Universidad Autónoma Metropolitana, México: 0.110 $\mathrm{kg} /$ person / day $[6,7]$

- Universidad Autónoma del Estado de Morelos $0.082 \mathrm{~kg} /$ person / 6 day approximately [14]

- Tecnológico de Monterrey campus León, Guanajuato, México $0.0963 \mathrm{~kg} /$ person / day [15]

Nevertheless, it can be observed that it's a low indicator compared with the generation per capita in Mexico for 2008, which was $0.97 \mathrm{~kg} /$ person/day [16], the UTL only generated in 2008 and 2009: 86.33 tons of waste. From which nearly $26 \%$ were recovered for their later appreciation. The organic wastes are recovered in great quantities and were used to produce natural fertilizer. This is why the waste management program is the main component of SGA-UTL. Of the universities in the United States, Brown University recycles $31 \%$ of the waste, the University of Florida $30 \%$, and finally one of the most successful programs of waste handling is the University Santa Clara in California, which recycles around $50 \%[4]$.

The composition compared to other universities, for example, Universidad Autonoma de Baja California Mexicali I campus, the waste with greater generation in buildings was paper, and in their gardens and their community center were organic waste (between $54 \%$ and $80 \%$ ) [4], in the cafeteria of the UTL (between 24 and 34\%) and in its gardens is where the most organic waste are generated.

The special waste handling plan, which is the base for all the operation of the storage center, exists since 2008. Nevertheless, all the indicators inside the continuous betterment cycle, shown and discussed here, are in constant upgrading.

Even though there were a lot of activities in 2008 and 2009 in regards to the waste management program, there is still room for betterments, from facilities of the storage center to betterments in the process of collecting waste and measuring indicators. To achieve these betterments, it is required a multi-task job in conjunction with other areas of the university, because the handling of solid waste has a lot of complex components that require different abilities and knowledge to find the best solution to this problem. Since
2009, we have looked for the cooperation of other degrees, as well for technological development.

All that has been mentioned here has required a significant investment in time, money, and effort from teachers, students, and personnel in general. Nevertheless, it is the duty of each educational institution to generate knowledge and to generate innovation in technology to solve environmental problems, and the most important to teach by example. Also with actions that will lead us to be coherent with what is taught inside the classrooms, especially for students of environmental degrees.

For 2010, Rectory has expressed their interest in obtaining an ISO 14001 certification, which will support and motivate a lot of the activities mentioned before, but this also implies a great challenge in terms of time, effort and investment.

Therefore, we can conclude that a lot of work is still needed and a lot of future challenges will have to be overcome to achieve significant advances in waste handling, especially in Mexican universities, because depending on the advances obtained, this will help to minimize the negative impact caused by the same universities. This essay is a contribution to demonstrate specific and detailed indicators, and real life experience by implementing a waste management program, because few universities document their achievements and contribute with real changes in Mexico for the institutions that are starting their own programs and for the rest that need to better their established programs.

\section{GLOSSARY}

Inorganic waste: All waste with economical value; here we include plastic, paper (without counting napkins or toilet paper), carton, metal, and aluminum (without counting aluminum paper).

Organic waste: It only refers to organic matter; here we exclude plastic, paper, and carton, because that's the system of separating that we have implemented; this way is better for its later recycling because it maintains the waste free from food and other.

Garbage: Refers to the waste that can't be recycled or converted into natural fertilizer, or the waste mixed in primary segregation, which are sent to their final disposal at the local sanitary landfill.

Efficiency: It is defined as the level of achievement of the objectives of the program.

Organic matter: They are waste from food, gardening and other waste that can be converted into natural fertilizer (compost)

\section{ACKNOWLEDGEMENTS}

We want to thank the UTL for providing the financial resources to operate the waste management program, as also to all the university's community for participating in the different activities.

We also want to thank CONCYTEG (Consejo de Ciencia y Tecnologia del Estado de Guanajuato) for their financial contributions to the realization of the quantitative analysis of 2009. 
We want to thank Jose de Jesus Mendoza Rivas and Julian Barragan Diaz, English coordinators of the UTL, for revising the English version of the essay and for all their comments to improve the article, and thanks to the Sergio Rico for the final translation and review of the article.

To all the professors of the Environmental Technology degree, especially Javier Paramo Vargas, who started a lot of the activities of the waste management program.

To Benito Juarez Rodriguez who was the first operator of the storage center and for his participation in a lot of the activities of UCC during 2008.

To the students of the Environmental Technology degree: Beatriz Padilla Rizo, Jose Salud Lara Servin, and Israel Rico Vera for their invaluable participation in the waste sampling of 2009.

And last but not least, a special acknowledgement for all the students of the Environmental Technology degree that have participated since 1999 till 2010 to maintain alive this project.

\section{REFERENCES}

[1] J. L. Palacios, "Un caso de estudio: Universidades Verdes." CONCYTEG's Gazette ideas, Year 3. Number 32. México: CONCYTEG, 2008, pp. 41-43.

[2] B. I. Estrada, J. M. González, F. G. Hernández, V. Pérez, G. A. Piña and M. P. Regalado, "Asesoría en el Sistema de Gestión Ambiental en la UTL", Superior Universitary Technician disertation, Universidad Tecnologica de Leon, Leon, Gto., México, 2007.

[3] M. B. Reyes, "Implantación de controles operacionales para el SGA-UTL", Superior Universitary Technician disertation, Universidad Tecnologica de Leon, Leon, Gto., México, 2008.

[4] C. Armijo, S. Ojeda and M. E. Ramírez, "Caracterización de residuos sólidos: el potencial de reciclaje para una institución de educación superior", First meeting of solid waste experts, México, Baja California: Universidad Autónoma de Baja California, 2007, pp. 76-89.

[5] M. Aguirre, "Plan de manejo de residuos para la Universidad Iberoamericana de León", Superior Universitary Technician disertation, Universidad Tecnologica de Leon, Leon, Gto., México, 2008.

[6] R. M Espinoza, M. S. Turpin, A. de la Torre, R. C. Vázquez, I. Delfín, B. González and A. L. Cisneros, "Proceso de implementación de un sistema internacional de administración de calidad en un programa de gestión integral de residuos sólidos en la Universidad Autónoma Metropolitana-Azcapotzalco", Second meeting of solid waste experts, México, Michoacán: Universidad Michoacana de San Nicolás de Hidalgo, 2009.

[7] R. M. Espinosa, S. Turpin, G. Polanco, A. De la Torre, I. Delfín and M.I. Raygoza, "Programa de gestión integral de residuos sólidos en la UAM Azcapotzalco: Una experiencia camino al éxito", First meeting of solid waste experts, México, Baja California: Universidad Autónoma de Baja California, 2007, pp. 336-347.

[8] Universidad Tecnologica de León, "Quienes somos?: Historia de la UTL", UTL's oficial Web page., [Online]. Available from: http://www.utleon.edu.mx//index.php?option=com content\&task= view\&id=22 \&Itemid=95. [Accessed: March 26, 2009].

[9] K. G. López, "Plan de manejo de residuos para la Universidad Tecnológica de León", Superior Universitary Technician disertation, Universidad Tecnologica de Leon, Leon, Gto., México, 2008

[10] NMX-SAA-14031-IMNC-2002, "Gestión Ambiental- Evaluación del desempeño ambiental-directriz", México: Instituto Mexicano de Normalización y certificación, A.C., 2003. Translation of the norm ISO 14031,1999

[11] D. E. Turcott, K. G. López and M. B. Reyes, "Informe anual del programa de manejo de residuos". México: Universidad Tecnologica de Leon, 2008.

[12] D. E. Turcott, L. Muñoz, K. G. López and M. B. Reyes, "Informe anual del programa de manejo de residuos". México: Universidad Tecnologica de Leon, 2009.

[13] B. Juarez, K. G. López and M. B. Reyes, "Bitácora electrónica de entradas de residuos de manejo especial y peligrosos". Electronic Book in Microsoft (C) Excel, from UCC. México: Universidad Tecnologica de Leon, 2008, 2009 and 2010.

[14] M. L. Ortiz, E. Sanchez and J. Lara, "La gestion mediambiental en la Universidad Autonoma del Estado de Morelos, Mexico". IV Internacional seminary of University and environment, Gestion ambiental institucional $\mathrm{y}$ ordenamiento de los campus universitarios compilated by O. Saenz, Bogota, Colombia, 2007, pp. 77-90.

[15] D. E. Turcott, L. Muñoz, K. G. López, M. B. Reyes, M. B. Murillo and V. Chávez, "El manejo de residuos en las instituciones de educación superior: El caso de las Universidades en Guanajuato". Third meeting of solid waste experts, Mexico, Distrito Federal, Universidad Autonoma Metropolitana, vol. 1, pp. 9-11, June 2010.

[16] Secretaría de Medio Ambiente y Recursos Naturales, "Generación total y per cápita de residuos sólidos urbanos". National system of environmental and natural resources. Basis indicators set, urban solid waste; Pressure indicator 4-2, 2008, Available from: http://www.semarnat.gob.mx/informacionambiental/Pages/indexsniarn.aspx, [Accesed: July $1^{\text {st }}, 2009$ ]. 